Polgári Szemle, 16. évf. 4-6. szám, 2020, 404-413., DOI: 10.24307/psz.2020.1032

Kiss Livia Benita

\title{
A hazai élelmiszeripari beruházások alakulásának ökonómiai kérdései 2013-tól napjainkig
}

\section{Economic Issues in the Development of Domestic Food Industrial Projects, from 2013 to Date}

Összefoglalás

Az élelmiszeripari beruházások teljesítményértéke növekvố tendenciát mutat a vizsgált idôszakban. A beruházások jelentôs része gépekre és berendezésekre irányult, valamint épületekre, építményekre, amiket javarészben saját forrásból finanszíroztak az élelmiszeripari vállalkozások. A saját forrás felhasználása mellett banki hitelbôl és támogatások igénybevételével valósították meg beruházásaikat. A TOP 5 élelmiszeripari szakágazatok közül a baromfihús-feldolgozás és -tartósítás, az egyéb gyümölcs- és zöldségfeldolgozás, valamint az üdítooital- és ásványvízgyártás szakágazatokban történtek a legnagyobb mértékú és legjelentôsebb beruházások. A bruttó termelési értékkel azonos mértékben, folyamatosan növekedtek az élelmiszeripari vállalkozások ráfordításai a vizsgált idốszakban. 2013-ban negatív eredménnyel zárták az évet, 2014-tôl 2017ig azonban már enyhén, de folyamatosan növekedett, majd 2018-ban és 2019-ben jelentôsen növekedett az üzemi tevékenység eredménye ezeknél a vállalkozásoknál.

Journal of Economic Literature (JEL) kódok: E22, L66, Q13, Q14, Q18

Kulcsszavak: beruházások, mezôgazdaság, élelmiszeripar, finanszírozás, pénzügyek

Summary

The performance of food industrial projects shows an increasing trend in the pe-

Dr. Kiss Lívia Benita, tanszéki mérnök, Szent István Egyetem, Georgikon Kar, Gazdasági, Társadalomtudományi és Vidékfejlesztési Tanszék (kiss.livia. benita@szie.hu). 


\section{Tudományos múhely}

riod under review. A significant part of the projects concerned machinery and equipment, buildings and structures, which were mostly financed from food industrial companies' own resources. In addition, they also borrowed from banks and applied for grants. Among Hungary's TOP 5 food industry lines, the largest and most significant projects were made in poultry meat processing and canning, other fruit and vegetable processing, and soft drink and mineral water production. To the extent of the gross production value, the expenses of food enterprises increased continuously in the period under review. Although these companies ended the year 2013 with a loss, between 2014 and 2017 their operating profit increased slightly but continuously, and in 2018 and 2019 it increased significantly.

Journal of Economic Literature (JEL) codes: E22, L66, Q13, Q14, Q18

Keywords: CapEx projects, agriculture, food industry, financing, finances

\section{Bevezetés}

A rendszerváltás és az Európai Unióhoz való csatlakozás hatására végbement permanens társadalmi, gazdasági és technikai változások, a tulajdonviszonyok, a birtokstruktúra, az éghajlatváltozás problémájának elótérbe kerülése miatt a fenntartható és környezetbarát termelés, a folyamatosan szigorodó minôségi elvárások, elốrások igen komoly és szigorú követelményeket állítanak a mezôgazdaság technikai, múszaki erôforrásaival szemben. Minden vállalkozás tevékenységét, jövốbeli sikerességét alapvetôen és hosszú távon befolyásolják, valamint meghatározzák a beruházásaikkal kapcsolatos döntéseiket. E döntések megfelelố elốkészítése, a minden szempontból legkedvezóbb alternatíva kiválasztása nemcsak a vállalkozások, hanem a nemzetgazdaság érdeke is (Daróczi, 2004).

E tanulmány a magyar élelmiszeripari vállalkozások esetében 2013-tól 2019-ig tár- gyalja a kapcsolódó beruházások alakulását. A vizsgált tételek között szerepel:

- az élelmiszeripari beruházások teljesítményértéke;

- az élelmiszeripari beruházások összetétele (épület/egyéb építmény, gépek/berendezések, jármúvek és egyéb);

- az élelmiszeripari beruházások finanszírozásának módja (saját forrás, banki hitel, támogatás, egyéb kölcsön, egyéb).

A tanulmány célja átfogó képet adni hazánk élelmiszeripari beruházásainak alakulásáról és jelenlegi helyzetéról. Emellett célkitûzése ezen élelmiszeripari vállalkozások vizsgált idôszakra vonatkozó pénzügyi helyzetének elemzése, a bruttó termelési érték, a ráfordítások és az üzemi tevékenység eredményének vizsgálatával. A beruházások alakulása önmagában nehezen értelmezhetô, mivel több folyamatot is visszatükrözô, összefüggéseket kifejezô indikátorról van szó. A beruházások jól mutatják a vállalkozások jövôvel kapcsolatos várakozásait, és jól leképezik a gazdaságpolitika, valamint monetáris politika irányultságát is (MOSZ, 2019).

Az elemzésekhez az Agrárgazdasági Kutató Intézet és a Központi Statisztikai Hivatal tényadatait (pénzügyi adatok) és várható (beruházások) adatait használtam. A vizsgált idôszakot meghatározta, hogy milyen idôközönként adtak ki statisztikai jelentéseket az élelmiszeripari beruházásokhoz és az élelmiszeripari vállalkozások pénzügyi helyzetéhez kapcsolódóan, így az összehasonlító elemzés a 2013-tól 2019-ig tartó idôszakot öleli fel, Microsoft Office 2013 Excel program, valamint annak adatelemzó funkciója és a GRETL szoftver alkalmazásával.

\section{SZAKIRODALMI ÁTTEKINTÉS}

Elsôként érdemes tisztázni az élelmiszer-gazdaság és az élelmiszeripar fogalmát. Az élelmiszer-gazdaság definíciója szúkebb értelemben a mezôgazdaságot és az élelmiszeripart, tágabban értelmezve a mezógazdaságot, az élelmiszeripart és az élelmiszer-ke- 


\section{Tudományos múhely}

reskedelmet (élelmiszer-forgalmazást) is magában foglalja. A gazdaság fejlódésével a mezôgazdasági termékek egyre jelentősebb része kerül élelmiszeripari feldolgozásra. Az élelmiszeripari termelés célja a növényi, az állati és az ásványi (ásványvíz) eredetú nyersanyagok emberi fogyasztásra történô előkészítése, feldolgozása. A mezôgazdasági termékek előállításához kapcsolódó tevékenységek és az élelmiszeripari feldolgozás közötti határvonal meghúzásában az játszik szerepet, hogy milyen mértékben alakulnak át a termékek alapvetố jellemzôi (Panyor, 2017).

A nemzetgazdaságon belül kulcsfontosságú szerepet tölt be az élelmiszer-gazdaság. Az élelmiszer-gazdasághoz szorosan kapcsolódik a mezőgazdaság, az élelmiszeripar és az élelmiszer-kereskedelem. E területeket vertikális összefonódás jellemzi, tehát egységes rendszert alkotnak. Hazánk az 5,4 millió hektár mezôgazdasági területtel és a kétmillió hektár erdôterülettel olyan élelmiszeripari potenciállal rendelkezik, amelyet messze nem használ ki (Panyor, 2017).

A vállalkozások tevékenységének eredményességét az egyes beruházások három területen befolyásolják: 1) A többleteredmény vagy a hatékonyabb termelés révén a vállalkozás nyereségére hatnak; 2) A likviditási helyzet alakítása révén, amely a kivitelezési idôszak kiadástöbbletét, a beruházásokhoz kapcsolódó hitelek törlesztését, valamint a múködtetés során jelentkezô bevételeket foglalja magában; 3) A vállalkozások vagyoni helyzetének (a vagyon nagyságának és összetételének) megváltoztatása révén (Kovács et al., 2015). Az élelmiszeripar beruházási hajlandóságán lemérhetô, mennyi jövedelem keletkezik az ágazat tevékenységének folytatása eredményeképpen, illetve a gazdasági szereplő́k hogy vélekednek az üzleti kilátásokról.

A hatékonyság és a versenyképesség növelése a magyar mezógazdaság és élelmiszeripar egyik legfontosabb kérdése, hiszen az élelmiszerekkel szemben egyre növekvố fogyasztói elvárások, az éghajlatváltozás, a szigorodó környezetvédelmi elvárások közepette rendkívül fontos a hatékonyság növelése. A beruházások hozzájárulnak a termelés modernizálásához, automatizálásához, aminek hatására a munkaerôhiány okozta problémák mérséklődnek. „Ahhoz, hogy Magyarország beérje az EU legfejlettebb mezógazdasággal rendelkezô tagországait, mindenképpen elengedhetetlen az agrárágazat tudás- és technológiaalapú modernizálása és az azt elôsegítô beruházások folytatása" (MTI, 2019).

A hazai termelés, piac hatékonyabb szervezésével, a termékek feldolgozottságának növelésével, a keresletet figyelembe vevó, célirányos termeléssel a jelenleginél $60 \%$ kal nagyobb termelési potenciál rejlik az élelmiszer-gazdaságban. A szektor egyik legnagyobb problémája a forráshiány volt, amelynek mérséklésére a 2014 és 2020 közötti uniós támogatási periódusban az élelmiszer-feldolgozás fejlesztésére 300 milliárd Ft állt rendelkezésre. A mikro- és kisvállalkozások a Vidékfejlesztési Program forrásaiból 200 milliárd Ft-ra, míg a közepes vállalkozások a Gazdaságfejlesztési és Innovációs Operatív Program forrásaiból 100 milliárd Ft-ra pályázhattak (Panyor, 2017).

A beruházások és támogatások eredményeképp azutóbbi években megduplázódott az élelmiszeripar nyeresége. „A legnagyobb beruházási kedv a baromfi-feldolgozóiparban volt tetten érhetô, ami az ágazat jövedelemtermelô képességével és jó piaci kilátásaival magyarázható" (Agrárszektor.hu, 2019).

\section{EREDMÉNYEK}

\section{Beruházások alakulása}

2013-ban kevéssel több, mint 72 milliárd Ft-ot fordítottak élelmiszeripari beruházásokra, ugyanakkor 2014-ben már több mint 100 milliárd Ft volt ezen beruházások értéke, ami 40,3\%-kal haladta meg az elózó évi 


\section{Tudományos múhely}

értéket. Ezzel szemben 2015-ben csak közel 90 milliárd Ft-ot fektettek be az élelmiszeripar fejlesztésébe, ami 11,4\%-kal alacsonyabb összeg volt, mint 2014-ben. 2016-ban újfent több mint 105 milliárd Ft-ot fordítottak élelmiszeripari beruházásokra, ami 17,5\%-kal magasabb érték volt, mint 2015ben. Az élelmiszeripari fejlesztések értéke jelentôsen növekedett (68,3\%) 2017-ben, több mint 177 milliárd Ft-ra. 2018-ban közel 170 milliárd Ft-ot költöttek élelmiszeripari beruházásokra, ami 4,7\%-kal alacsonyabb volt az elôzô évinél. Az élelmiszeripari beruházások értéke - több mint 200 milliárd forint - 18,7\%-kal magasabb volt 2019-ben, mint egy évvel korábban. 2013-tól 2019-ig megháromszorozódott az élelmiszeripari beruházások értéke.

Az 1. táblázat az élelmiszeripari beruházások értékének részesedését mutatja az összes nemzetgazdasági beruházások értékéből. A vizsgált idôszakból kiemelkedik a 2017-es és a 2019-es év.

A 1. ábra az élelmiszeripari beruházások összetételének teljesítményérték-alakulását mutatja. Az élelmiszeripari beruházások összetételét tekintve, az élelmiszeripari vállalkozások a legnagyobb részben, közel 43 milliárd Ft értékben gépekre és berendezé- sekre $(59,5 \%)$, valamint épületekre és építményekre (30,6\%) költöttek 2013-ban, és csak kis részben jármúvekre $(3,4 \%)$. A gépek és berendezések beruházásainak jelentôs mértékú bôvüléséhez az élelmiszer-feldolgozás technológiai fejlesztése céljából igénybe vehetô támogatások, illetve pályázatok járultak hozzá. 2014-ben a beruházások összetétele alapján az élelmiszeripari beruházásokra fordított teljes összeg 63,3\%át (több mint 64 milliárd Ft) gépekre és berendezésekre, 26,5\%-át épületekre és építményekre, 5,3\%-át jármúvekre fordították. Az élelmiszeripari beruházások kiadásainak 59,9\%-át (közel 54 milliárd Ft) gépekre és berendezésekre, 29,1\%-át épületekre és építményekre, 6\%-át jármúvekre költötték 2015-ben. A beruházások közül a gépekre és berendezésekre fordított beruházások értéke csökkent a legjelentősebben. 2016ban a beruházások összetétele alapján az élelmiszeripari beruházásokra fordított összeg 61,2\%-át (több mint 64 milliárd Ft) gépekre és berendezésekre, 28,1\%-át épületekre és építményekre, 5,8\%-át jármúvekre adták ki. Az élelmiszeripari beruházások kiadásainak 60,6\%-át (több mint 107 milliárd Ft) gépekre és berendezésekre, 29,7\%-át épületekre és építményekre,

1. táblázat: Élelmiszeripari beruházások részesedése az összes nemzetgazdasági beruházásból (2013-2019)

\begin{tabular}{l|c|c|c}
\hline $\mathbf{E}$ Év & $\begin{array}{c}\text { Összes nemzetgazdasági } \\
\text { beruházás értéke } \\
\text { (ezer Ft) }\end{array}$ & $\begin{array}{c}\text { Élelmiszeripari } \\
\text { beruházások értéke } \\
\text { (ezer Ft) }\end{array}$ & $\begin{array}{c}\text { Élelmiszeripar részesedése } \\
\text { az összes nemzetgazdasági } \\
\text { beruházásból* }\end{array}$ \\
\hline $\mathbf{2 0 1 3}$
\end{tabular}

Forrás: Saját számítás* és szerkesztés Kiss, 2013; Csoltai, 2015-2020; KSH STADAT alapján 
1. ábra: Élelmiszeripari beruházások összetételének teljesitményérték-alakulása (2013-2019, ezer Ft)

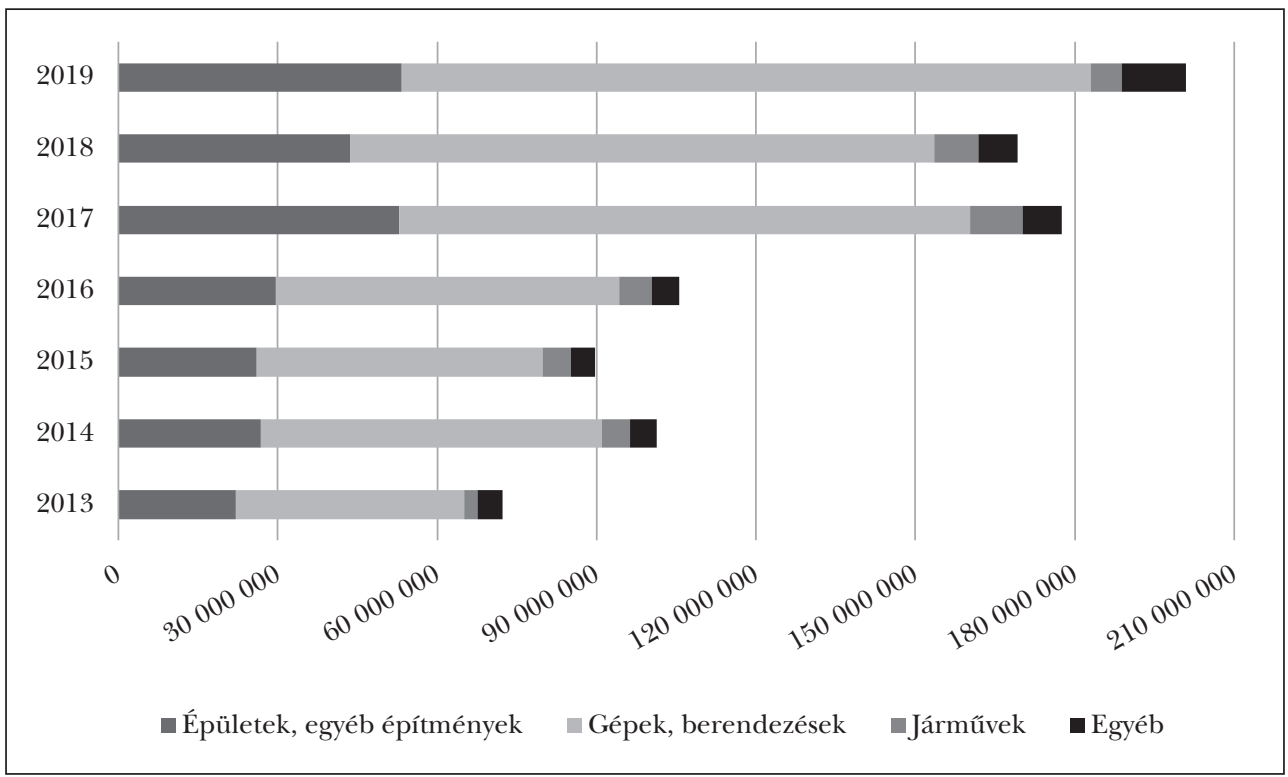

Forrás: Saját szerkesztés Kiss, 2013; Csoltai, 2015-2020 alapján

5,6\%-át jármúvekre költötték 2017-ben. 2018-ban az élelmiszeripari beruházásokra fordított teljes összeg 65\%-át (közel 110 milliárd Ft) gépekre és berendezésekre, 25,7\%-át épületekre és építményekre, 5\%át jármúvekre fizették ki. Az élelmiszeripari beruházások összetételét tekintve, az élelmiszeripari vállalkozások a legnagyobb részben, közel 130 milliárd $\mathrm{Ft}$ értékben gépekre és berendezésekre $(64,6 \%)$, valamint épületekre és építményekre (26,5\%) költöttek 2019-ben, és csak kis részben jármúvekre $(2,9 \%)$. Összességében tehát a vizsgált beruházások jelentôs része $(60 \%$ és felette) gépekre és berendezésekre irányult, valamint épületekre, építményekre (20-30\%).

Az élelmiszeripari beruházások finanszírozásának eloszlását vizsgálva, 2013-ban a legnagyobb részben, közel 57 milliárd Ft értékben saját forrásból $(78,5 \%)$ finanszírozták. A banki hitelbốl történô finanszírozást csupán 6,5\%-ban vették igénybe a vállalkozások, és támogatásból szintén 7\%-ban fizették a beruházásokat. A beruházásokat 2014-ben is nagyrészt saját erôbôl (közel 79 milliárd Ft) finanszírozták, 77,8\%-ban. A banki hitel aránya a beruházásban a 2013. évi 6,5\%-ról 8,6\%-ra emelkedett. A támogatásból történố beruházásfinanszírozás 7,3\%-ot tett ki. Ahogy 2013-ban és 2014-ben, úgy 2015-ben is nagyrészt saját erôból $(82,5 \%)$ finanszírozták a beruházásokat, ami közel 74 milliárd Ft kiadást jelentett a vállalkozásoknak. A banki hitel aránya a beruházásban a 2014. évi 8,6\%-ról 2015-re 6,6\%-ra változott. A támogatásból történô beruházásfinanszírozás 3,8\%-ot tett ki, ami jelentôs csökkenés volt az elózó évekhez képest.

2016-ban szintén legnagyobb részben saját erôbôl $(82 \%)$ finanszírozták a beruházásokat, ami közel 87 milliárd Ft-ot tett ki. A banki hitel aránya a beruházásokban a 2015. évi 6,6\%-ról 2016-ra 11\%-ra emelkedett. A támogatásból történó beruházásfinanszírozás tovább csökkent, már csak 2,7\%-ot tett ki. Az elôzó évekhez hasonlóan 2017-ben is leginkább saját eróbôl $(76,3 \%)$ 


\section{Tudományos múhely}

finanszírozták a beruházásokat, ami már több mint 135 milliárd Ft kiadást jelentett a vállalkozásoknak. A banki hitel a 2016. évi 11\%-ról 2017-re 13,2\%-ra emelkedett. A támogatásból történô beruházásfinanszírozás 8,7\%-ot tett ki, ami jelentôs növekedést mutatott a vizsgált elôzô két évhez képest. A beruházásokat 2018-ban is szintén nagyrészt saját erôból $(65,7 \%)$ - több mint 111 milliárd Ft értékben - finanszírozták a vállalkozások, míg 2017-ben ez az arány
$76,3 \%$ volt. A banki hitel a 2017. évi 13,2\%ról 2018-ra 19,2\%-ra emelkedett. A támogatásból történô beruházásfinanszírozás mértéke tovább növekedett, 9,2\%-ot tett ki. A beruházásokat 2019-ben újfent nagyrészt saját erôből (71,1\%), közel 143 milliárd Ft értékben fizették a vállalkozások, 2018-ban ez az arány $65,7 \%$ volt. A banki hitel aránya 16,4\%-ra csökkent 2019-ben. A támogatásból történố beruházásfinanszírozás 8,3\%-ot tett ki (2. ábra).

2. ábra: Élelmiszeripari beruházások finanszírozásának eloszlása (2016-2019)
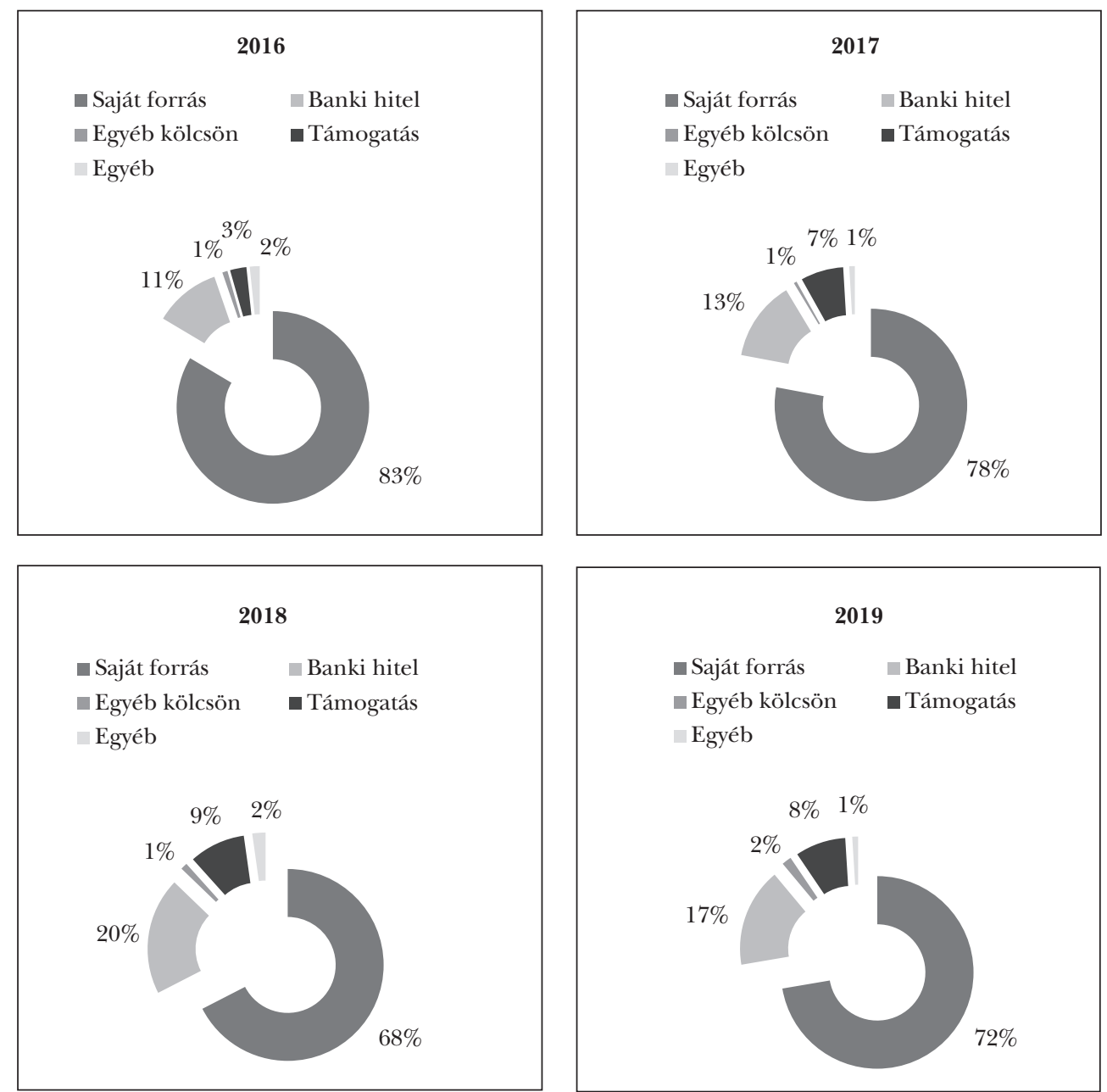

Forrás: Saját szerkesztés Kiss, 2013; Csoltai, 2015-2020 alapján 


\section{Tudományos múhely}

A TOP 5 szakágazat beruházásának teljesítményértékét tekintve, a legnagyobb volumenú beruházások 2013-ban az édesség- (1082), tejtermék- (1051), dohánytermék- (1200) és haszonállateledel-gyártás (1091), valamint baromfihús-feldolgozás, -tartósítás (1012) szakágazatokban történtek, amik az összes élelmiszeripari beruházás közel 44\%-át tették ki. 2014-ben az egyéb gyümölcs- és zöldségfeldolgozás (1039), a dohánytermék gyártása, a szôlóbortermelés (1102), a hús- (1011), valamint a baromfihús-feldolgozás és -tartósítás szakágazatok beruházásainak teljesítményértéke volt kiemelkedô, amik együtt az összes élelmiszeripari beruházás 40,6\%-át tették ki. A legnagyobb értékú beruházások az egyéb gyümölcs- és zöldségfeldolgozás, a szőlőbortermelés, a tejtermékgyártás, a hús, valamint a baromfihús-feldolgozás és -tartósítás szakágazatokban voltak 2015-ben, az összes élelmiszer-ipari beruházás 42\%-át adták.

2016-ban a legnagyobb volumenú beruházások az édességgyártás, az üdítôital-, ásványvízgyártás (1107), az olajgyártás (1041), egyéb gyümölcs-és zöldségfeldolgozás, valamint a kenyér- és frisspékáru gyártás (1062) szakágazatokban valósultak meg, amik együtt az összes élelmiszeripari beruházás 37,1\%-át tették ki. 2017-ben az édességgyártás, a tésztafélék gyártása (1073), a baromfihús-feldolgozás és -tartósítás, az üdítôital-, ásványvízgyártás, valamint a máshova nem sorolt élelmiszergyártás (1089) szakágazatok beruházásainak teljesítményértéke volt kiemelkedô, az összes élelmiszeripari beruházás 39,7\%-át adták. A legnagyobb értékú beruházások a baromfihús-feldolgozás, az üdítóital-, ásványvízgyártás, a tejtermék gyártása, az édességgyártás, valamint a kenyér-, frisspékáru-gyártás szakágazatokban történtek 2018-ban, amelyek együtt az öszszes élelmiszeripari beruházás 46,9\%-át tették ki. A legnagyobb beruházás összességében az alábbi szakágazatokban történt 2019-ben: keményítógyártás, üdítôital-, ásványvízgyártás, tejtermékgyártás, dohány- termékgyártás, valamint baromfihús-feldolgozás és -tartósítás. Ez az öt szakágazat az élelmiszeripar teljes beruházásának 46,1\%át adta.

\section{Pénzügyi helyzetkép}

A 2. táblázat az élelmiszeripari vállalkozások fóbb pénzügyi adatait foglalja össze. A bruttó termelési értéket az értékesítés nettó árbevétele, az egyéb bevételek és az aktivált saját teljesítmények értéke adja. A ráfordítások az anyag jellegú és a személyi jellegú ráfordításokat, az értékcsökkenési leírást, valamint az egyéb ráfordításokat tartalmazzák. A bruttó termelési értékkel azonos mértékben, folyamatosan növekedtek az élelmiszeripari vállalkozások ráfordításai is a vizsgált idôszakban. Míg 2013-ban összesen a bruttó termelési érték 148161 millió Ft volt a vállalkozásoknál, addig 2019-ben már 368384 millió Ft. A ráfordítások a 2013-as évi 155463 millió Ft-ról 350227 millió Ft-ra növekedtek.

A 3. ábra az üzemi tevékenység eredményének alakulását szemlélteti 2013 és 2019 között az élelmiszeripari vállalkozások esetében. Az üzemi tevékenység eredményét a bruttó termelési érték és a ráfordítás különbsége adja.

Az oszlopdiagram jól szemlélteti, hogy 2013-ban negatív eredménnyel (-7302 millió Ft) zárták az évet az élelmiszeripari vállalkozások. 2014-tôl 2017-ig azonban már az látható, hogy enyhén, de folyamatosan növekedett (1132 millió Ft-ról 2103 millió Ft-ra), majd 2018-ban (15 161 millió Ft) és 2019-ben (18 157 millió Ft) jelentôsen növekedett az üzemi tevékenység eredménye ezeknél a vállalkozásoknál.

\section{ÖSSZEFOgLALÁS}

Hazánk mezôgazdaságának versenyképességét megórizni és javítani csak permanens mûszaki fejlesztések, beruházások útján van lehetôség. Az Agrárminisztérium komplexen tekint az agrárágazatra, hiszen a mezô- 


\section{Tudományos múhely}

2. táblázat: Élelmiszeripari vállalkozások föbb pénzügyi adatai (2013-2019)

\begin{tabular}{l|c|c|c|c|}
\hline $\mathbf{E ́ v}$ & $\begin{array}{c}\text { Bruttó termelési } \\
\text { érték (millió Ft) }\end{array}$ & $\begin{array}{c}\text { Ráfordítások } \\
\text { (millió Ft) }\end{array}$ & $\begin{array}{c}\text { Üzemi tevékenység } \\
\text { eredménye (millió Ft) }\end{array}$ & $\begin{array}{c}\text { Üzemi tevékenység } \\
\text { változása* (\%) }\end{array}$ \\
\hline $\mathbf{2 0 1 3}$ & 148161 & 155463 & -7302 & - \\
\hline $\mathbf{2 0 1 4}$ & 153602 & 152471 & 1132 & 745,05 \\
\hline $\mathbf{2 0 1 5}$ & 162516 & 161444 & 1073 & 94,79 \\
\hline $\mathbf{2 0 1 6}$ & 180475 & 178846 & 1629 & 151,82 \\
\hline $\mathbf{2 0 1 7}$ & 195326 & 193224 & 2103 & 129,10 \\
\hline $\mathbf{2 0 1 8}$ & 342935 & 327774 & 15161 & 720,92 \\
\hline $\mathbf{2 0 1 9}$ & 368384 & 350227 & 18157 & 119,76 \\
\hline Összesen* & 1551399 & 1519449 & 31953 & - \\
\hline Átlag* & 221628 & 217064 & 4565 & - \\
\hline
\end{tabular}

Forrás: Saját számítás* és szerkesztés Kiss, 2013; Csoltai, 2015-2020 alapján

3. ábra: Üzemi tevékenység eredményének alakulása az élelmiszeripari vállalkozásoknál (20132019, $M$ Ft)

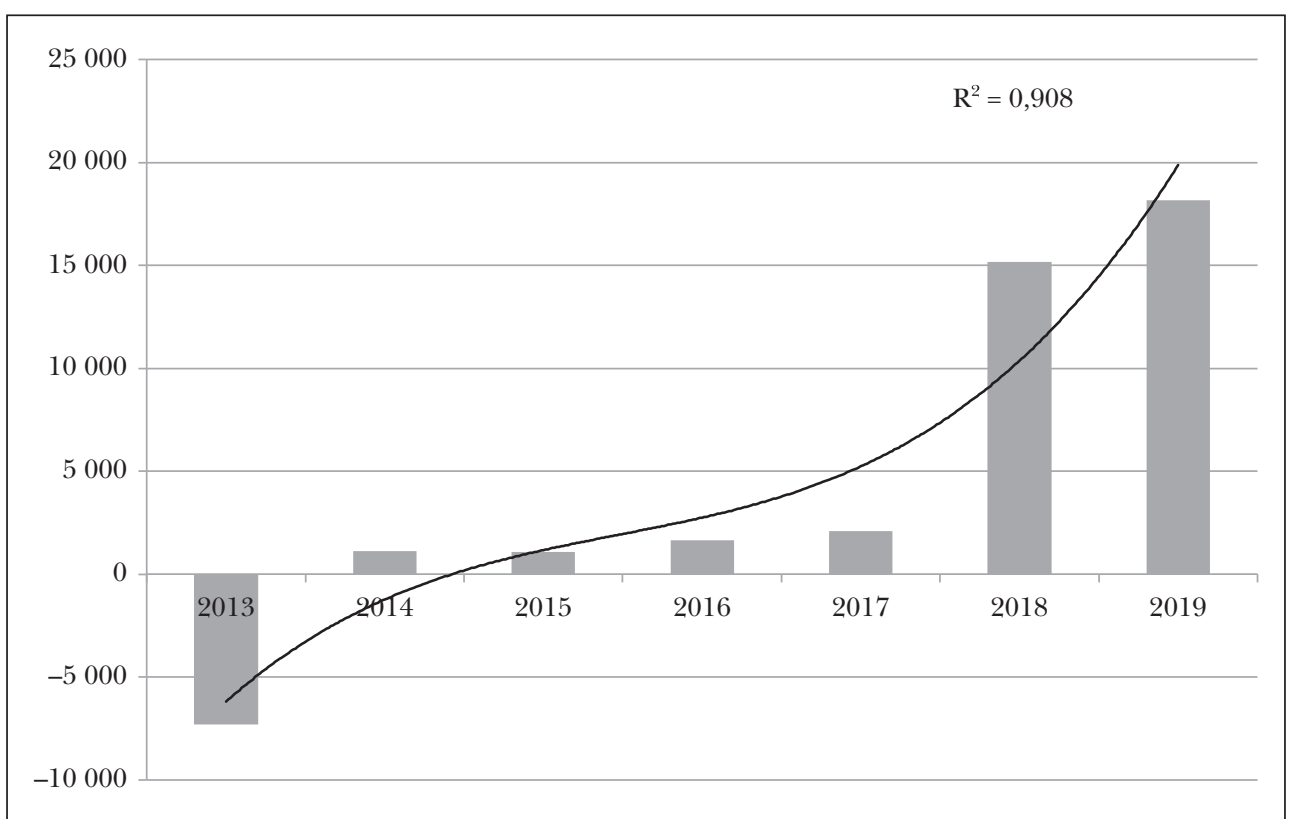

Forrás: Saját szerkesztés Kiss, 2013; Csoltai, 2015-2020 alapján

gazdaság nem elválasztható a kapcsolódó, az inputjait szállító és outputjait fogadó gazdasági területektôl, így például az élelmiszeriparral, azaz az élelmiszer-feldolgozással, az élelmiszer-kereskedelemmel szoros szimbiózisban tevékenykedik. Az élelmiszer-gazda- ság biztosítja a különféle termékek előállítását, emellett hozzájárul a vidéki életminőség javításához és a munkahelyek teremtéséhez, fenntartásához. A mezôgazdaság fejlődése szempontjából meghatározó szektornak számít az élelmiszeripar, mint a termények fó 


\section{Tudományos múhely}

felvevőpiaca, valamint a vidéki foglalkoztatás és jövedelem növelését is elősegítő szektor.

Az élelmiszeripari beruházások teljesítményértéke növekvô tendenciát mutat a vizsgált, 2013 és 2019 közötti idôszakban. A beruházások jelentôs része (60\% és afelett) gépekre és berendezésekre irányult, valamint épületekre, építményekre (20$30 \%$ ), melyeket javarészben saját forrásból (70-80\%) finanszíroztak az élelmiszeripari vállalkozások. A saját forrás felhasználása mellett banki hitelból (átlagban 11,6\%) és támogatások (átlagban 7,1\%) igénybevételével valósították meg beruházásaikat. A TOP 5 élelmiszeripari szakágazatok közül a baromfihús-feldolgozás és -tartósítás, az egyéb gyümölcs- és zöldségfeldolgozás, valamint az üdítôital- és ásványvízgyártás szakágazatokban történtek a legnagyobb mértékú és legjelentősebb beruházások.

A bruttó termelési értékkel azonos mértékben, folyamatosan növekedtek az élelmiszeripari vállalkozások ráfordításai is a vizsgált időszakban. 2013-ban az élelmiszeripari vállalkozások negatív eredménnyel zárták az évet. 2014-től 2017-ig azonban már enyhén, de folyamatosan növekedett, majd 2018-ban és 2019-ben jelentôsen növekedett az üzemi tevékenység eredménye ezeknél a vállalkozásoknál.

Jelentôsen nôttek a támogatások, és kedvezményes hitelprogramok is indultak az élelmiszeriparban. A Vidékfejlesztési Programban megítélt, körülbelül 1300 milliárd Ft támogatásból 620 milliárd Ft beruházási célokat szolgál, ami azt jelenti, hogy a következó idôszakban jelentôs technológiafejlesztésre és teljesítménynövekedésre lehet számítani az élelmiszer-gazdaságban, amely természetesen a versenyképesség növeléséhez is hozzájárul majd. A magyar élelmiszeripar dinamikusan fejlődô terület, amely nemcsak az agráriumnak, hanem az egész hazai gazdaságunknak meghatározó alappillére, ezért az ágazat jövôje stratégiai jelentôségú.

\section{FelHaSZnÁlt IRODALOM}

Agrárszektor.hu (2019): Ezek a legprosperálóbb élelmiszeripari ágazatok! Agrárszektor.hu, www. agrarszektor.hu/elemiszer/ezek-a-legprosperalobb-elelmiszeripari-agazatok.14309.html (Letöltés: 2020. július 2.).

Csoltai Veronika (2015): A beruházások és a fôbb pénzügyi mutatók várható alakulása az élelmiszeriparban 2014-ben. Statisztikai Jelentések, 8. évf., Agrárgazdasági Kutató Intézet, www.aki.gov. hu/publikaciok/publikacio/a:358/a_beruhazasok_es_penzugyi_mutatok_varhato_alakulasa (Letöltés: 2020. június 25.).

Csoltai Veronika (2016): A beruházások és a fơbb pénzügyi mutatók várható alakulása az élelmiszeriparban 2015-ben. Statisztikai Jelentések, 9. évf., 1. sz., Agrárgazdasági Kutató Intézet, www. aki.gov.hu/publikaciok/publikacio/a:358/a beruhazasok_es_penzugyi_mutatok_varhato_ alakulasa (Letöltés: 2020. június 25.).

Csoltai Veronika (2017): A beruházások és a fơbb pénzügyi mutatók alakulása az élelmiszeriparban 2016-ban. Statisztikai Jelentések, 10. évf., 1. sz., Agrárgazdasági Kutató Intézet, www.aki.gov. hu/publikaciok/publikacio/a:358/a_beruhazasok_es_penzugyi_mutatok_varhato_alakulasa (Letöltés: 2020. június 25.).

Csoltai Veronika (2018): A beruházások és a fơbb pénzügyi mutatók alakulása az élelmiszeriparban 2017. év. Statisztikai Jelentések, 11. évf., 1. sz., Agrárgazdasági Kutató Intézet, http://repo.aki. gov.hu/3156/1/Beruh\%C3\%A1z\%C3\%A1s_ \%C3\%A9lipkiadv\%C3\%A1ny2017.pdf (Letöltés: 2020. június 25.).

Csoltai Veronika (2019): A beruházások és a fơbb pénzügyi mutatók alakulása az élelmiszeriparban 2018. év. Statisztikai Jelentések, 12. évf., 1. sz., NAIK Agrárgazdasági Kutatóintézet, http://repo.aki. gov.hu/3385/1/Beruha\%CC\%81za\%CC\%81s_ e\%CC\%81lipkiadva\%CC\%81ny2018.pdf (Letöltés: 2020. június 25.).

Csoltai Veronika (2020): A beruházások és a fơbb pénzügyi mutatók várható alakulása az élelmiszeriparban 2019. év. Statisztikai Jelentések, 13. évf., 1. sz., NAIK Agrárgazdasági Kutatóintézet, http://repo.aki.gov.hu/3560/1/Beruh\%C3\% A1z\%C3\%A1s_\%C3\%A9lipkiadv\%C3\%A1ny 2019.pdf (Letöltés: 2020. június 25.). 


\section{Tudományos múhely}

Daróczi Miklós (2004): Mezógazdasági beruházások komplex döntés-elôkészitése. PhD-értekezés, Szent István Egyetem, Gödöllô.

Kiss Gabriella (2013): A beruházások és a fôbb pénzügyi mutatók várható alakulása az élelmiszeriparban 2013-ban. Statisztikai Jelentések, 7. évf., Agrárgazdasági Kutató Intézet, www.aki.gov.hu/publikaciok/publikacio/a:358/a_beruhazasok_es_penzugyi_mutatok_varhato_alakulasa (Letöltés: 2020.június 25.).

Kovács Árpád Endre - Szalay Zsigmond Gábor Klárné Barta Éva (2015): Az idôbeni pénzáramok kezelése a gazdasági számításokban. Studia Mundi-Economica, 2. évf., 2. sz., 93-106.

KSH (2020): A nemzetgazdasági beruházások értéke, volumenindexei (2000-). KSH, www.ksh.hu/docs/ hun/xstadat/xstadat_eves/i_qb001.html.

MOSZ (2019): Elôterjesztés az elnökség részére a mezốgazdasági beruházások alakulásáról és annak okairól.
Mezôgazdasági Szövetkezôk és Termelốk Országos Szövetsége, Budapest.

MTI (2019): A hatékonyság növelése a magyar mezôgazdaság legfontosabb kérdése. Kormany.hu, www.kormany.hu/hu/foldmuvelesugyi-miniszterium/hirek/a-hatekonysag-novelese-a-magyar-mezogazdasag-legfontosabb-kerdese (Letöltés: 2020. július 2.).

Panyor Ágota (2017): A magyar élelmiszergazdaság jellemzôi és kihívásai a XXI. században. Jelenkori Társadalmi és Gazdasági Folyamatok, 12. évf., 3. sz., 107-112.

Seitz, Wesley D. - Nelson, Gerald C. - Halcrow, Harold G. (1994): Economics of Resources, Agriculture, and Food. McGraw Hill, New York.

Tracy, Michael (1994): Élelmiszertermelés és mezôgazdaság a piacgazdaságban. Pannon Agrártudományi Egyetem, Keszthely. 